\title{
Construction and improvement of intervention mechanism for the plight children's growth environment based on Delphi method
}

\author{
Li Shuyan, Gao Guimei \\ Preschool Education and Special Education College, Kunming University, Kunming 650214, China
}

Keywords: the plight children, Delphi method, intervention mechanism

\begin{abstract}
It is the common responsibility of the government, society and family to provide a good growth environment for the plight children, so we need to improve the plight children's growth environment, the protection measures of the plight children based on the Delphi method of evaluation, has important significance to realize the healthy growth of the plight children better.
\end{abstract}

\section{Introduction}

Children are the most important and valuable human resources of the nation. Since the reform and opening up, China has experienced rapid economic development and great social change, population structure and people's way of life has undergone changes in turn the world upside down, these changes have significant impact on children's growth environment and life style, the increasing number of the plight of children. The plight of children has become a hot topic in the government and academic circles, and it is urgent to solve this problem.

\section{Reflection on the intervention system of children's growth environment}

The laws and regulations related to the plight of children are imperfect. There are many laws and regulations protecting children in our country. For example, the "People's Republic of China Education Law", "general principles of civil law", "People's Republic of China juvenile crime prevention law" and other laws and regulations, which points out the direction for the protection and development of children and children's welfare, but if the use of specific to the plight of children relief work will be found in the related law is imperfect, imperfect phenomenon. The general principles of the civil law of the people's Republic of China and the law of the People's Republic of China on the prevention of juvenile delinquency have clearly defined the legal duties of guardians, but these statutory responsibilities lack detailed and specific explanations. For example, parents go out to work, although parents are guardians of their children, but because they do not go home for a long time to visit their children, they can not perform their duties well. At the same time, the legal obligations and responsibilities of the clients are not clear. The parents and other guardians are not in custody and neglect of duty, which is an important reason for the frequent occurrence of the plight of children.

The state has not implemented the problem of ensuring the plight of children. China's children's subsidy system is still in the exploratory stage, in response to national policy, the country has introduced a pilot policy. In June 2016, China stipulated the basic principles of the general principles of the civil law of the people's Republic of China and the law of the People's Republic of China on the prevention of juvenile delinquency and the plight of children's protection work. We put forward the establishment of a sound working system for the plight of children, but the specific measures still need to be refined and implemented. The main reason is that China's child welfare policy is fragmented, overlapping and scattered in the adult social security system, and can not really meet the needs of children. The general principles of the civil law of the people's Republic of China and the law of the People's Republic of China on the prevention of juvenile delinquency 
fundamentally restrict the state's efforts to protect children in distress. Second, our country does not have the extension classification of the plight children in the documents of various local governments, which causes the fragmentation of the region seriously.

There is not enough emphasis on the role of families in child support. Family is an important place for children's socialization and plays a positive role in children's socialization into the city. But in the process of taking care of the plight of children, as the family will encounter a series of difficult problems to solve, it is necessary to provide external help to reduce the economic pressure caused by major diseases and congenital defects. Although the security system of government departments can provide some difficulties for children in a certain degree, they can not replace the important role of family in children's growth. Therefore, in the process of designing the system, the government not only plays the role of providing services, but also should play the role of coordination between the government and the family.

\section{The improvement of the environment intervention mechanism for the plight of children}

Clear the main responsibility of the government, improve the relevant laws. According to the experience of overseas children protection, in most developed countries, the protection and relief work of children are undertaken by the special government departments. If you want to continue to develop and perfect the corresponding laws and regulations, establishing and perfecting the social welfare system, we should firstly system a series of laws and regulations for the protection of children, such as child welfare, welfare law etc., and on this basis, we should perfect it and establish a unified system of child welfare.

The state should set up special child protection institutions. First of all, the country should make clear the main tasks of helping children in distress. There are many aspects of child protection work, child welfare mainly includes the following aspects, such as economic benefits, daily care, education and protection, labor protection, cultural protection, the main content is to protect the welfare of her. Therefore, China must set up a sound and sound institution for the welfare of children, the protection of children and the relief of children, and the organization and training of professional personnel, in addition, adequate funding will be provided.

Encourage the training of professional personnel of social work. In order to better establish a child protection system, it is necessary to realize the specialization of the means of rescue for children in distress. So, in the case of rescuing troubled children, we should strengthen the training of a professional service team, and also encourage professionals in the community to join the relief work for the plight children. At the same time for those who want to help the plight of children volunteers and NGOs can be free to provide professional training courses, to help them through the national social work occupation level examination, obtain the professional qualification certificate, in order to establish a professional social workers and volunteers with the plight of children rescue team, to provide professional services the plight of the healthy growth of children, so that children can grow up healthy and happy.

\section{Assessment of the growth environment intervention mechanism for children in distress Based on Delphy method}

Delphy method is a very effective predictor of judgment, it is done by investigators in advance of a questionnaire, looking for authoritative experts to form a group, through mail, so that each expert to fill out a questionnaire, the investigators then processed the questionnaire answers of experts, and then asked each expert for their opinion. After repeated consultation, expert advice and expert feedback process, until the expert's advice gradually reached unity, the consultation work is over.

Identify the experts involved. The evaluation system for the construction of the project for the protection of the plight of children requires that the participating experts have a good understanding of the project, at the same time, they should also have certain authority in the field of child protection, and only in this way can we ensure that the indicators are more reasonable and accurate 
in the construction. Therefore, in the study of experts, we should start with three aspects, namely, Civil Affairs Bureau, university research professionals and relief professional organizations.

Specifically, the criteria for college professors are: interest in the study, high participation, and long-term work related to child welfare and child care.

For the Civil Affairs Bureau staff, the selection criteria are: interested in this research, high participation enthusiasm; familiar with the work and policies in the project; more than 10 years of work.

A staff member of a professional organization. The standard of selection is to be interested in this research and to be highly motivated; the principal person in charge of the organization is working in the service of the children in distress.

In this study, the author inquired about 12 experts, including 4 people in charge of Civil Affairs Bureau, 4 professors in Colleges and universities, and 4 people in charge of institutions.

Design of evaluation system for intervention mechanism of growth environment. Prior to this study, the author collected information on the work of children's emergency stations,

And the plight of children in a city as the focus of the object, to design indicators. The process actually breaks down the project into a number of small processes, and every time a process is completed, it is assumed that the task has been accomplished a little. According to this process, the author identifies four dimensions, policy environment, publicity, prevention, discovery, reporting and assessment support. In determining the initial indicators, for each dimension, looking for appropriate evaluation indicators. Finally, the initial index system of 7 first level indexes and 14 two level indexes is formed. The specific process is shown below:

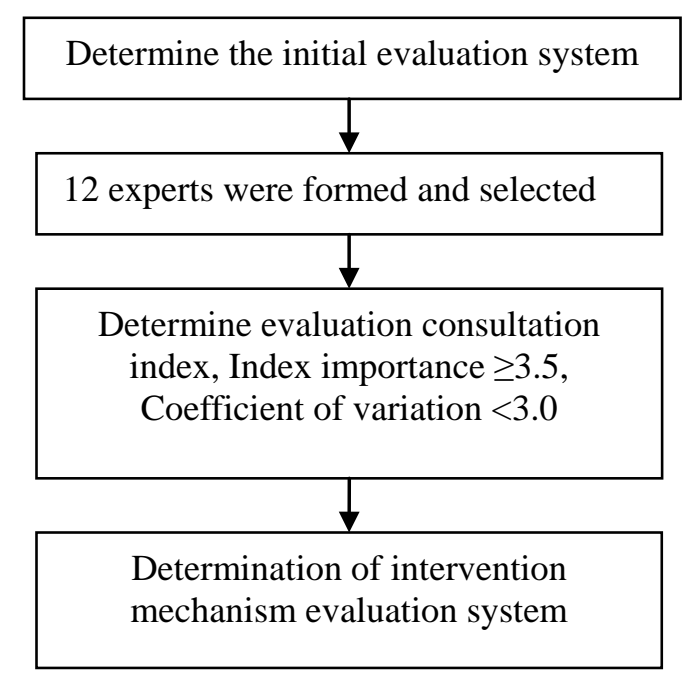

Fig. 1 Design process of intervention mechanism evaluation system

Results obtained by consulting evaluation experts. In the construction of the first round of indicators system, there are 7 first level indicators and 14 two level indicators. 12 mails were sent to the experts, and 12 were recovered, with a recovery rate of $100 \%$. Including 7 experts over the age of 40 , and the proportion is $58 \%$, there are 5 experts between 30 to 40 years old, and the proportion is $42 \%$, Of these, $80 \%$ experts are master's degrees. The results of the expert consultation are shown in Table 1. Among them, the index score is average less than 3.5 points, or the coefficient of variation is greater than or equal to 0.3 of the indicators are highlighted. 
Table 1 The scoring results of expert consultation

\begin{tabular}{|c|c|c|c|c|c|c|}
\hline Dimension & Primary index & Index meaning & Secondary indexes & Index meaning & $\begin{array}{l}\text { Average } \\
\text { value }\end{array}$ & $\begin{array}{l}\text { Coefficient } \\
\text { of } \\
\text { variation }\end{array}$ \\
\hline \multirow{2}{*}{$\begin{array}{c}\text { Policy } \\
\text { environment }\end{array}$} & \multirow{2}{*}{ Policy support } & \multirow{2}{*}{$\begin{array}{l}\text { Regulations } \\
\text { guidance and } \\
\text { the working } \\
\text { mechanism } \\
\text { establishment } \\
\text { of } \\
\text { government's } \\
\text { efforts to save } \\
\text { and protect } \\
\text { children in } \\
\text { distress }\end{array}$} & Policy formulation & $\begin{array}{l}\text { The government has } \\
\text { formulated policies } \\
\text { and regulations for the } \\
\text { rescue and protection } \\
\text { of children in the } \\
\text { plight }\end{array}$ & 5 & 0.00 \\
\hline & & & Working system & $\begin{array}{l}\text { The government has } \\
\text { formulated policies } \\
\text { and regulations for the } \\
\text { rescue and protection } \\
\text { of children in related } \\
\text { difficulties }\end{array}$ & 4.75 & 0.11 \\
\hline \multirow{4}{*}{$\begin{array}{l}\text { Propaganda } \\
\text { and } \\
\text { Prevention }\end{array}$} & \multirow[b]{2}{*}{$\begin{array}{c}\text { Publicity } \\
\text { content }\end{array}$} & \multirow{2}{*}{$\begin{array}{l}\text { In propaganda, } \\
\text { the publicity of } \\
\text { information } \\
\text { content and } \\
\text { subject matter }\end{array}$} & $\begin{array}{l}\text { Content } \\
\text { innovation }\end{array}$ & $\begin{array}{l}\text { Innovation degree of } \\
\text { Information content in } \\
\text { the campaign to } \\
\text { Interpretation of } \\
\text { relevant policies and } \\
\text { regulations and forms } \\
\text { of publicity }\end{array}$ & 3.5 & 0.37 \\
\hline & & & Social education & $\begin{array}{l}\text { Purpose, method and } \\
\text { significance of the } \\
\text { information content in } \\
\text { the campaign can } \\
\text { clearly and } \\
\text { systematically explain } \\
\text { the plight of children } \\
\text { relief and protection } \\
\text { projects }\end{array}$ & 3.5 & 0.37 \\
\hline & \multirow[b]{2}{*}{$\begin{array}{l}\text { Propaganda } \\
\text { method }\end{array}$} & \multirow{2}{*}{$\begin{array}{l}\text { Propaganda } \\
\text { plan and the } \\
\text { specific } \\
\text { implementation } \\
\text { process of the } \\
\text { dissemination } \\
\text { of methods and } \\
\text { skills, channels }\end{array}$} & Media publicity & $\begin{array}{l}\text { Media coverage of } \\
\text { troubled children's } \\
\text { rescue and protection } \\
\text { programs, sectors, } \\
\text { coverage and hits }\end{array}$ & 3.75 & 0.34 \\
\hline & & & Scheme planning & $\begin{array}{l}\text { The rationality and the } \\
\text { degree of refinement } \\
\text { of the methods and } \\
\text { techniques chosen in } \\
\text { the campaign, and the } \\
\text { degree of fit with the } \\
\text { subject }\end{array}$ & 3.25 & 0.39 \\
\hline \multirow[t]{2}{*}{$\begin{array}{l}\text { Discovery } \\
\text { Report }\end{array}$} & \multirow[t]{2}{*}{$\begin{array}{l}\text { Mandatory } \\
\text { report }\end{array}$} & \multirow[t]{2}{*}{$\begin{array}{l}\text { Mandatory } \\
\text { reporting } \\
\text { system }\end{array}$} & $\begin{array}{l}\text { Establishment of } \\
\text { society protection } \\
\text { network }\end{array}$ & $\begin{array}{l}\text { A special community } \\
\text { reporting team will be } \\
\text { established in the } \\
\text { community. The } \\
\text { community secretary } \\
\text { or director will act as } \\
\text { supervisor and receive } \\
\text { professional training } \\
\text { to effectively carry } \\
\text { out the work }\end{array}$ & 4.25 & 0.12 \\
\hline & & & $\begin{array}{l}\text { Establishment of } \\
\text { school protection } \\
\text { network }\end{array}$ & $\begin{array}{l}\text { The school establishes } \\
\text { a protective network, } \\
\text { performs its } \\
\text { obligations } \\
\text { effectively, and } \\
\text { reports voluntarily }\end{array}$ & 4.5 & 0.13 \\
\hline
\end{tabular}




\begin{tabular}{|c|c|c|c|c|c|c|}
\hline & \multirow[t]{2}{*}{$\begin{array}{l}\text { Initiative } \\
\text { discovery }\end{array}$} & \multirow{2}{*}{$\begin{array}{l}\text { Preliminary } \\
\text { screening of } \\
\text { children in } \\
\text { difficult areas } \\
\text { by streets and } \\
\text { community } \\
\text { committees }\end{array}$} & $\begin{array}{c}\text { Expertise of } \\
\text { investigation } \\
\text { personnel }\end{array}$ & $\begin{array}{l}\text { The degree of } \\
\text { specialization of the } \\
\text { personnel involved in } \\
\text { the investigation. } \\
\text { Such as educational } \\
\text { background, work } \\
\text { experience, training } \\
\text { times and so on }\end{array}$ & 3.5 & 0.37 \\
\hline & & & Innovativeness & $\begin{array}{l}\text { In the investigation } \\
\text { work, the use of } \\
\text { innovative means and } \\
\text { methods to improve } \\
\text { the efficiency of the } \\
\text { investigation work }\end{array}$ & 3 & 0.47 \\
\hline \multirow{4}{*}{$\begin{array}{c}\text { Assessment } \\
\text { support }\end{array}$} & \multirow[b]{2}{*}{$\begin{array}{c}\text { Risk } \\
\text { assessment }\end{array}$} & \multirow{2}{*}{$\begin{array}{l}\text { Professional } \\
\text { institutions to } \\
\text { assess the risk } \\
\text { of screening } \\
\text { personnel }\end{array}$} & Risk screening & $\begin{array}{l}\text { The professional } \\
\text { organization carries } \\
\text { out the risk grading } \\
\text { work on the newly } \\
\text { screened objects }\end{array}$ & 4 & 0.2 \\
\hline & & & $\begin{array}{l}\text { Emergency } \\
\text { response }\end{array}$ & $\begin{array}{l}\text { Flexibility to take } \\
\text { effective measures, } \\
\text { and then the ability to } \\
\text { rescue in accordance } \\
\text { with procedures when } \\
\text { there is no time to } \\
\text { assess an incident }\end{array}$ & 4.75 & 0.11 \\
\hline & \multirow[b]{2}{*}{$\begin{array}{l}\text { Intervention } \\
\text { service }\end{array}$} & \multirow{2}{*}{$\begin{array}{l}\text { Assistance by } \\
\text { professional } \\
\text { organizations } \\
\text { to key cases in } \\
\text { primary } \\
\text { families }\end{array}$} & service content & $\begin{array}{c}\text { Whether novel or } \\
\text { original? }\end{array}$ & 3.5 & 0.37 \\
\hline & & & Service form & $\begin{array}{c}\text { Whether innovative } \\
\text { project } \\
\text { implementation } \\
\text { innovative? }\end{array}$ & 3.5 & 0.37 \\
\hline
\end{tabular}

(1) Indicators to be deleted;

As can be seen from the above Table 1, there are several indicators in the assessment that need to be deleted. From the expert's point of view, mainly because the two indicators design is unreasonable, too refined. Although publicity is important, the most important thing is to advertise it.

(2) Increase of indicators;

We need to increase the "investigation results" this secondary indexe. The probability of missing samples is also determined by sampling and reexamination. In the evaluation and assistance, two levels of indicators, "service content" and "service form" have been added". The connotation of service content is that the content of service should conform to the needs of the case, and the meaning, knowledge and service style of the service form should conform to the actual family situation of the plight children.

(3) Modify the index;

Through the analysis of expert opinions, we need to change "the establishment of community protection network" and "the establishment of school protection network" under the mandatory reporting system into "reporting mechanism".

\section{Conclusion}

This paper summarizes the current plight of children's environment intervention system, and the corresponding optimization scheme has been put forward, and based on the analysis of the plight of children protection project, the construction of evaluation index was carried out by Delphy method. In order to provide the plight of children they need help, this method can be used to improve the protection system of the plight of children, and achieve the goal of social protection of minors system. 


\section{Acknowledgments}

The work was supported by two projects. One is from the Youth Project of National Social Science Foundation with item number 13CSH014.The one is from Natural Science Foundation of China with the Grant No. 71361023.

\section{Reference}

[1] Zhao Jiajia. Study on the problems and Countermeasures of the plight of children in China [J]. Legal System and Society, 20, (2015), p.174-175.

[2] Wang Zhishi. Research on the rescue and protection mechanism for children in troubled communities in Chengdu [D]. Southwest Jiao Tong University, (2015).

[3] Liu Shuang. Improvement of the legal system for the protection of minors' rights [D]. Jilin University of Finance and economics, (2014).

[4], Dai Chao. National salvation of troubled children from the perspective of child welfare theory [J]. contemporary youth research, No.03, (2014), p. 78-84.

[5] Yan Lixin. On the protection of the rights of the children left behind in rural China [D]. Hebei University of Economics and Business, (2014).

[6] Yang Yadu. China's visitation right system and its perfection -- From the perspective of the principle of maximizing the interests of children [J]. Social Sciences Review, No. 03, (2013), p.85-86.

[7] Bai Wenyong, Huang Guangfen, Qi Fang. Research on the strategy of difficult children relief from the perspective of social management innovation -- Based on the perspective of child welfare theory [J]. Journal of Yunnan Administrative College, No.02, (2013), p.137-140.

[8] Feng Yao. Research on crime control of street children [D]. Sichuan Normal University, 2013.

[9] Chen Kunlin. Cause analysis and Prevention Countermeasures of juvenile delinquency [D]. Fudan University, (2012).

[10] Wu Xue. Research on China's child welfare policy framework [D]. Nanjing University of Technology, (2012).

[11] Gu Xiaofen. Study on the role and approach of public security organs in the prevention and control of juvenile delinquency [D]. Shanghai Jiao Tong University, (2010). 